\title{
Molecular Assessment of Athecate Dinoflagellates of the Order Gymnodiniales (Dinophyceae) in Todos Santos Bay, Baja California México
}

\author{
Alexis De Jesús Escarcega-Bata1, Mary Carmen Ruiz-de la Torre ${ }^{1}$, María Luisa Nuñez Resendiz ${ }^{2}$, \\ Luis Manuel Enriquez-Paredes ${ }^{1}$, Kurt M. Dreckmann², Abel Sentíes ${ }^{2}$
}

${ }^{1}$ Marine Science Faculty, Autonomous University of Baja California, Ensenada, México

${ }^{2}$ Department of Hydrobiology, Universidad Autónoma Metropolitana-Iztapalapa, México, México

Email: escarcega.alexis@uabc.edu.mx, *mary.ruiz@uabc.edu.mx,mlnr@ciencias.unam.mx, 1menriquez@uabc.edu.mx,

kutodreckmann@gmail.com, asentiesg@gmail.com

How to cite this paper: De Jesús Escarcega-Bata, A., Ruiz-de la Torre, M.C., Resendiz, M.L.N., Enriquez-Paredes, L.M., Dreckmann, K.M. and Sentíes, A. (2021) Molecular Assessment of Athecate Dinoflagellates of the Order Gymnodiniales (Dinophyceae) in Todos Santos Bay, Baja California México. American Journal of Plant Sciences, 12, 1926 1944.

https://doi.org/10.4236/ajps.2021.1212133

Received: November 5, 2021

Accepted: December 25, 2021

Published: December 28, 2021

Copyright $\odot 2021$ by author(s) and Scientific Research Publishing Inc. This work is licensed under the Creative Commons Attribution International License (CC BY 4.0).

http://creativecommons.org/licenses/by/4.0/

\section{(c) (i) Open Access}

\begin{abstract}
The Gymnodiniales are the most important group of athecate dinoflagellates both for its abundance and distribution and for the harmful potential of several of its species. Although morphologically it is well known, phylogenetically it has been very little studied. HABs impact important coastal activities in Todos Santos Bay, so a detailed characterization of potentially toxic phytoplankton species is crucial in monitoring surveys. Therefore, the aim of the present study was to carry out a molecular assessment to the morphospecies of Gymnodiniales currently recorded in Todos Santos Bay, from which discussed their phylogenetic relationships. 120 samples were obtained from monthly samplings during 2019 to 2020. For all of them, $18 \mathrm{~s}$ small subunit (SSU) and $28 \mathrm{~s}$ large subunit (LSU) genes of rDNA were amplified and sequenced using single-cell PCR. Also, they were photographed. A phylogenetic analysis was performed on MrBayes from the combined $18 \mathrm{~s}-28 \mathrm{~s}$ data set. The presence of 15 phylogenetic entities was confirmed, four of which constituted new records for the Mexican Pacific, as well as three harmful species, one toxic and two bloom-forming. Our molecular results evidenced the need to re-evaluate the current taxonomic system of athecate dinoflagellates at all hierarchical levels, integrating them with morphological evidence without preponderance of this criterion over taxonomic decisions.
\end{abstract}

\section{Keywords}

Diversity, HABS, New Records, Paraphyletic Groups, Athecate Dinoflagellates 


\section{Introduction}

Dinoflagellates are the second most diverse group within phytoplankton and the most abundant group in tropical marine environments. They are mainly characterized by being solitary, mobile and unicellular, although sometimes they form chains, with variable size from $5 \mu \mathrm{m}$ to $2 \mathrm{~mm}$ [1] [2]. Currently, an estimated 2000 living species are known, divided into six classes, 16 orders, 65 families and 259 genera [3] [4] [5]. [6] classified them, according to the characteristics of their cell wall in Thecales and Athecales; the latter characterized by presenting a very fragile cell wall (amphysm) composed of very fine flattened vesicles [2], and two conventional flagella (one longitudinal housed in the sulcus and another transversal housed in the cingulum). For the discrimination of species within Athecates, different morphological characters are considered to discriminate them by size, position and displacement of flagella, presence or absence of an apical sulcus, chloroplasts and pyrenoids, position and size of the nucleus, folds or stretchmarks, as well as ornamentation and extensions on the wall [1]. Currently, they are not considered a natural group since they comprise various orders, being Syndiniales Loeblich III, Suessiales Fensome et al., and Noctilucales Haeckel the most ancestral phylogenetically, which suggests that the amphysm, its main morphological character, is equally ancestral [7].

Gymnodiniales Apstein has been the order most studied in the group of athecates, both for the number of species and ecological importance [8] [9]. It comprises an approximate of 638 species, divided into 11 families and 71 genera of which 29 are planktonic; Gymnodinium Stein, Gyrodinium Kofoid \& Swezy, Cochlodinium Schütt and Warnowia Lindemann group are the largest number of species [5] [10]. Although they are morphologically well known, their phylogenetic relationships have been little studied. However, from the few studies that have integrated morphology with molecular tools, some important changes have been made at all hierarchical levels. For example, [11] analyzed sequences of the $28 \mathrm{~s}$ rDNA gene in species of the genera Gymnodinium and Gyrodinium, erecting to Akashiwo Hansen \& Moestrup, Karenia Hansen \& Moestrup and Karlodinium Larsen. [12] succeeded in redefining Margalefidinium fulvescens (= Cochlodinium fulvescens) and [13] to Torquentidium flavescens (=Gyrodinium flavescens); [14] and [15], have also described new diversity at the specific and generic level.

On the coasts of the Mexican Pacific, even though several species have been identified as forming blooms, the diversity of Gymnodiniales is known exclusively on the morphological basis and is scarce [2] [16] [17] [18]. In the coastal zone of Baja California, particularly in the Todos Santos Bay (TSB), Harmful Algae Blooms (HABs) impact important coastal activities [19], so a robust characterization of the floristic composition with harmful potential is crucial in monitoring programs to detect potentially toxic phytoplankton. However, the only study of specific composition in the area is that of [18], also on a morphological basis, since this group is not known phylogenetically. Additionally, expe- 
rience and the instrumentation of microscopic observation limit the correct identification of harmful algae, especially athecate dinoflagellates. Given the above, the aim of the present study was to carry out a molecular assessment to the morphospecies of Gymnodiniales currently recorded in Todos Santos Bay, from which discussed their phylogenetic relationships.

\section{Material and Methods}

\subsection{Collection, Observation, and Isolation}

Monthly samplings were carried out from August 2019 to April 2020, aboard one smaller vessel, of which a total of 120 samples were obtained. The samples were collected from two different sampling campaigns, with twelve and eight different points, respectively (Figure 1). The biological material was obtained with a phytoplankton network of $20 \mu \mathrm{m}$ mesh size, by vertical dragging at each sampling point. The samples obtained were stored in plastic drums (covered

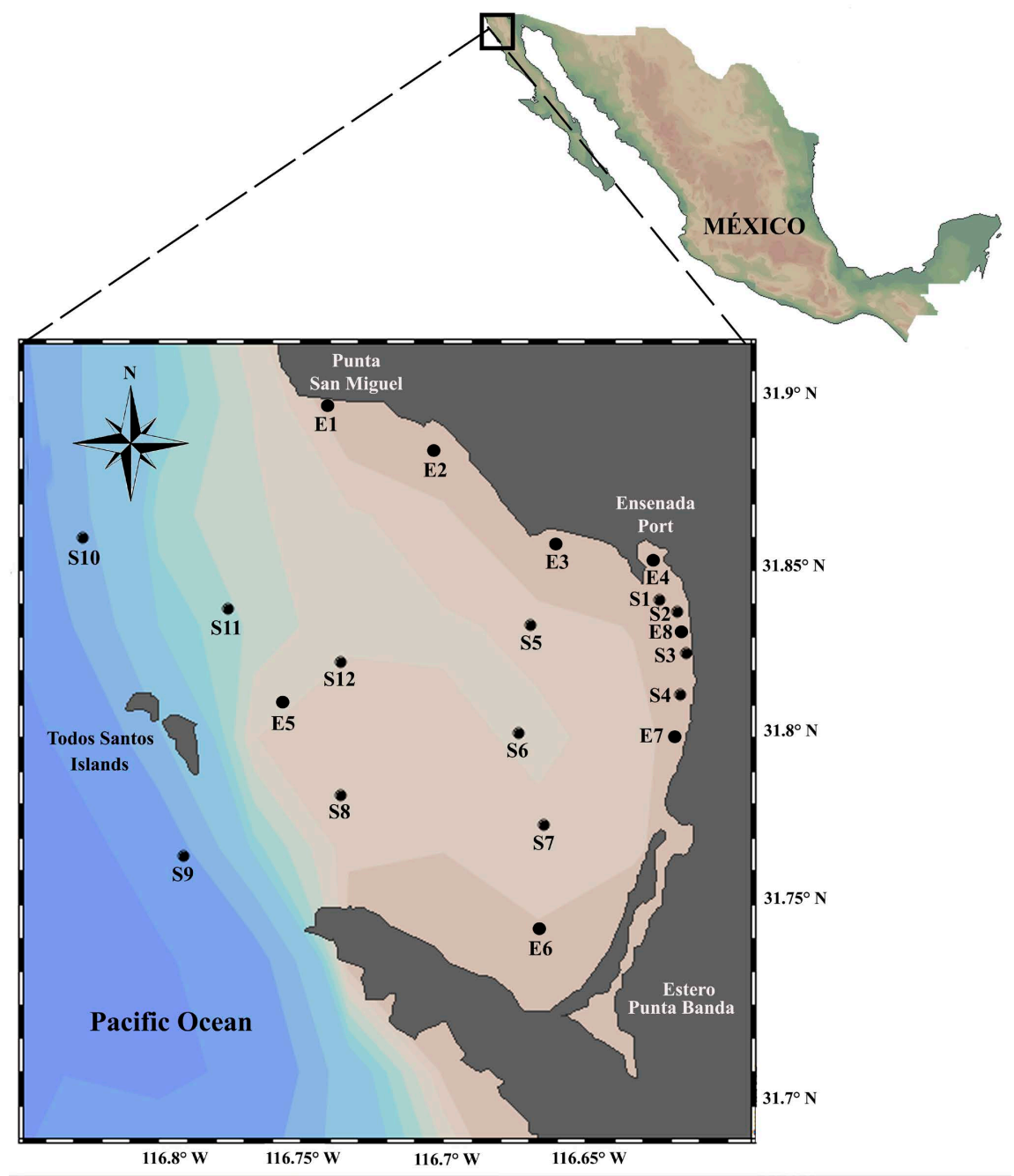

Figure 1. Study area with the sampling stations of the monitoring carried out inside and outside the Todos Santos Bay. The monthly collection stations are indicated by the letter "S" (S1 - S12) and the SEMAR collection stations are indicated by the letter "E" (E1 - E8). 
with tape to protect the collected material from sunlight) of $250 \mathrm{ml}$ capacity. To avoid deformation of the biological material, the samples were stored in containers with ice for later analysis in the laboratory. Live samples were filtered with a sieve with a mesh size of $130 \mu \mathrm{m}$, to eliminate zooplankton. For the observation of the collected material, a $15 \mathrm{ml}$ aliquot of each sample was taken and deposited in each well of a culture plate (Plate with 6 wells). Each well was viewed under a Leica DM IRB (Germany) inverted light microscope, with brightfield illumination at $10 \times$ magnification. Athecate cells were isolated by means of a reduced micropipette technique and rinsed several times with sterile filtered seawater. Single cells were placed in $0.2 \mathrm{~mL}$ PCR tubes and stored at $-80^{\circ} \mathrm{C}$ for subsequent molecular analysis. Those isolated cells that did not undergo deformation during the rinses were photographed with a Canon EOS-Rebel T6 camera (Taiwan).

\subsection{Single Cell-PCR and Sequencing}

The $18 \mathrm{~s}$ small subunit (SSU) and $28 \mathrm{~s}$ large subunit (LSU) genes of rDNA were amplified. Single cell PCR was performed directly following the protocols described by [20] and [21] with minor modifications described in the PCR conditions. The primers pairs combination for SSU [20] were SR1-F/SR12-R, SR1-F/SR7-R, SR1-F/SR9-R, SR4-F/SR7-R and SR4-F/SR9-R [20], for LSU D1R-F/D2C-R and D1R-F/D3B-R [22] [23]. The amplification conditions were, for the $18 \mathrm{~s}$ gene: initial denaturation at $98^{\circ} \mathrm{C}$ for $3 \mathrm{~min}, 35 \mathrm{cycles}$ at $95^{\circ} \mathrm{C}$ for $1 \mathrm{~min}, 56^{\circ} \mathrm{C}$ for 1 min and $72^{\circ} \mathrm{C}$ for $3 \mathrm{~min}$, with a final extension at $72^{\circ} \mathrm{C}$ for $10 \mathrm{~min}$; for the $28 \mathrm{~s}$ gene: initial denaturation at $98^{\circ} \mathrm{C}$ for $3 \mathrm{~min}, 35$ cycles at $95^{\circ} \mathrm{C}$ for $30 \mathrm{~s}, 52^{\circ} \mathrm{C}$ for $30 \mathrm{~s}$ and $72^{\circ} \mathrm{C}$ for $1 \mathrm{~min}$, with a final extension at $72^{\circ} \mathrm{C}$ for $10 \mathrm{~min}$. Amplification were confirmed through electrophoresis in 1.5\% agarose gels for $20 \mathrm{~min}$ at $90 \mathrm{~V}$, stained with Ethidium Bromide and visualized in an UV light gel documentation system. PCR products were stored at $-20^{\circ} \mathrm{C}$ and shipped to Retrogen Inc (San Diego, CA, USA) for purification and sequencing. DNA sequences were determined only for one strand using the corresponding forward/reverse primers.

\subsection{Phylogenetic Analysis}

The sequences obtained (Table 1), were aligned in BioEdit v. 7.0.5 [24] with those of a selected group of athecate species from the GenBank (Table S1). Syndinium turbo and Hematodinium perezii were used as outgroup because they have been used in other analysis with dinoflagellates. We analysed SSU-LSU gene-codon partitioned sequence data sets both separately and concatenated. For the combined $18 \mathrm{~s}-28 \mathrm{~s}$ data set, taxa for which $18 \mathrm{~s}$ or $28 \mathrm{~s}$ sequence data were unavailable were treated as missing data. Bayesian phylogenetic analyses were performed in MrBayes v3.2.2 [25] using a GTR + I + G (general time reversible + invariable sites + gamma distribution), evolutionary model, as suggested by the ML ratio test implemented by TOPALi v2 software [26]. Four parallele runs of the Markov Chain Monte Carlo (MCMC) searches were performed 
Table 1. Data for the isolated and sequenced athecate dinoflagellates (18 s small subunit (SSU) and 28 s large subunit (LSU)) in this study. The GenBank access number, collection station, and figure for each morphospecies are included. Dash (-) indicates that there was no photographic record of the morphospecies.

\begin{tabular}{|c|c|c|c|}
\hline Taxa & $\begin{array}{l}\text { GenBank } \\
\text { accession } \\
\text { number }\end{array}$ & $\begin{array}{l}\text { Collection } \\
\text { station }\end{array}$ & Figure \\
\hline $\begin{array}{c}\text { Akashiwo sanguinea (Hirasaka) } \\
\text { Hansen \& Moestrup }\end{array}$ & OL439705 & 1 & \multirow{4}{*}{$3(\mathrm{~A})$} \\
\hline A. sanguinea & OL439706 & 2 & \\
\hline A. sanguinea & OL439707 & 3 & \\
\hline $\begin{array}{l}\text { A. sanguinea } \\
\text { A. sanguinea }\end{array}$ & $\begin{array}{l}\text { OL439688 } \\
\text { OL439689 }\end{array}$ & 4 & \\
\hline $\begin{array}{c}\text { Balechina pachydermata (Kofoid \& Swezy) } \\
\text { Loeblich Jr., Loeblich III }\end{array}$ & OL439708 & 6 & $3(\mathrm{~B})$ \\
\hline Gymnodinium catenatum Graham & OL439693 & 11 & - \\
\hline G. sp. 1 & OL439690 & 12 & - \\
\hline $\begin{array}{l}G . \text { sp. } 2 \\
\text { G. sp. } 3\end{array}$ & $\begin{array}{l}\text { OL439691 } \\
\text { OL439692 }\end{array}$ & 11 & $3(\mathrm{C})$ \\
\hline $\begin{array}{c}\text { Gyrodinium heterostriatum } \\
\text { (Kofoid \& Swezy) Gómez, Artigas \& Gast }\end{array}$ & OL439710 & 10 & $3(\mathrm{D})$ \\
\hline Gyrodinium sp. & OL439709 & 9 & $3(\mathrm{E})$ \\
\hline $\begin{array}{l}\text { Levanderina fissa (Levander) Moestrup, } \\
\text { Hakanen, Hansen, Daugbjerg \& Ellegaard }\end{array}$ & OL439711 & 4 & - \\
\hline $\begin{array}{l}\text { Lepidodinium viride Watanabe, } \\
\text { Suda, Inouye, Sawaguchi \& Chihara }\end{array}$ & OL439694 & 5 & $3(\mathrm{G})$ \\
\hline $\begin{array}{l}\text { Margalefidinium fulvescens } \\
\text { (Iwataki, Kawami \& Matsuoka) } \\
\text { Gómez, Richlen \& Anderson }\end{array}$ & OL439712 & 1 & \\
\hline M. fulvescens & OL439713 & 2 & $3(\mathrm{H})$ \\
\hline M. fulvescens & OL439695 & 8 & \\
\hline M. fulvescens & OL439696 & 10 & \\
\hline M. fulvescens & OL439697 & 12 & \\
\hline $\begin{array}{c}\text { Pseliodinium fusus (Schütt) Gómez } \\
P \text { fusus }\end{array}$ & $\begin{array}{l}\text { OL439714 } \\
\text { OL439698 }\end{array}$ & 8 & $3(\mathrm{~J})$ \\
\hline $\begin{array}{c}\text { Takayama acrotrocha (Larsen) Salas, } \\
\text { Bolch \& Hallegraeff }\end{array}$ & OL439715 & 11 & - \\
\hline $\begin{array}{c}\text { T. tasmanica Salas, Bolch \& Hallegraeff } \\
\text { T. tasmanica }\end{array}$ & $\begin{array}{l}\text { OL439700 } \\
\text { OL439701 }\end{array}$ & 12 & $3(\mathrm{~F})$ \\
\hline T. sp. & OL439699 & 5 & - \\
\hline
\end{tabular}




\section{Continued}

Torquentidium flavescens (Kofoid \& Swezy)

Shin, Li, Lee \& Matsuoka

T. flavescens

T. flavescens
OL439702

OL439703

OL439704
6

$3(\mathrm{I})$

starting with a random tree, sampling the data every 100 generations for $5 \times 10^{6}$ generations, and discarding the first $25 \%$ of trees as burn-in. Pairwise distance values (p-distances) were calculated using Mega v5 [27].

\section{Results}

A total of 80 cells corresponding to athecate dinoflagellates were isolated for TSB, where only 60 amplified. Of the total of sequences obtained, only 28 corresponded to dinoflagellates of the order Gymnodiniales. Sequence analyses of athecate dinoflagellates from TSB SSU-LSU obtained through single-cell PCR, confirmed the presence of 15 phylogenetic entities, four of which constituted new records for the Mexican Pacific (Gyrodinium heterostriatum, Lepidodinium viride, Torquentidium flavecens and Takayama acrotrocha). The Gymnodiniacea family was the largest represented with seven species, followed by Kareniaceae, Ceratoperidiniaceae and Gyrodiniaceae, each with two species and two other species in an uncertain position.

The alignment with SSU consisted of 56 sequences, 11 newly ones generated in this study, with a length of 1229 base pairs (bp), while the alignment with $28 \mathrm{~s}$ large subunit (LSU) consisted of 75 sequences, 16 newly generated in this study, with a length $976 \mathrm{bp}$. In the combined $18 \mathrm{~s}-28 \mathrm{~s}$ analysis (Figure 2) and in all single analyses, BI trees did not differ, but there were slight differences among markers due to sampling or in poorly supported branches; so, we only describe the results from the combined analysis SSU-LSU (Figure 2).

Phylogenetic reconstruction based on the concatenated data set showed seven large clades (Figure 2). Clade I, with low phylogenetic support $(\mathrm{BI}=0.65)$, showed two sister subclades (A and B). Subclade A, with high phylogenetic support $(B I=0.99)$, sequences from the Genbank and sequences generated in this study for the genus Margalefidinium were grouped (Figure 3(H)). Subclade B, with good phylogenetic support $(\mathrm{BI}=0.85)$, grouped GenBank sequences and generated in this study for the sister genera Levanderina and Akashiwo (Figure $3(\mathrm{~A})$ ). Clade II, belonging to the Kareniaceae family, with low phylogenetic support $(\mathrm{BI}=0.60)$, was made up of GenBank sequences for the sister genera Karlodinium and Takayama (Figure 3(F)), which in turn were resolved in a larger clade as sisters of Karenia. Of our sequences only Takayama was represented in this clade. Clade III, belonging to the Ceratoperidiniaceae family, with the maximum phylogenetic support $(\mathrm{BI}=1)$, was made up of sequences generated in this study and from GenBank, for the sister genera Torquentidium and Pseliodinium (Figure $3(\mathrm{I})$ and Figure $3(\mathrm{~J})$ ), which in turn were resolved into 


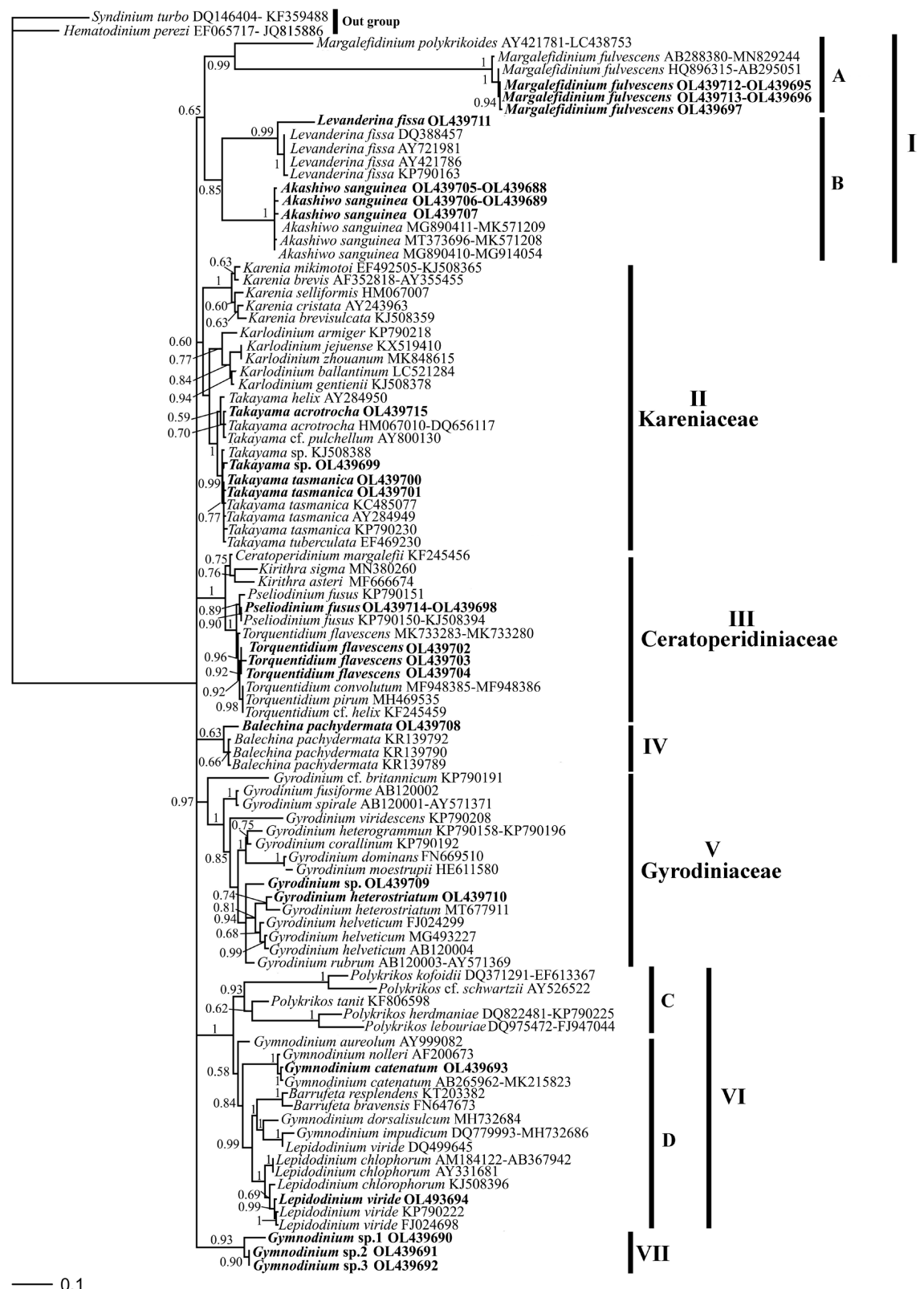

Figure 2. Bayesian topology based on the combined data set SSU-LSU rDNA for Gymnodiniales species. The numbers at the nodes are the Bayesian posterior probability (PPB) values. The main clades are indicated by Roman numerals (I, II, III, IV, V, VI, VII). Subclades are indicated by letters ((A), (B), (C), (D)). The sequences generated in this study are in bold. The bar under the tree indicates substitutions by site.

a larger clade such as sister of Kirithra and Ceratoperidinium. Clade IV, with low phylogenetic support $(\mathrm{BI}=0.63)$, was made up of GenBank sequences and generated in this study for the genus Balechina (Figure 3(B)). Clade V, belonging to the Gyrodiniaceae family, with high phylogenetic support $(B I=0.97)$, was made up of GenBank sequences and sequences generated in this study for the genus Gyrodinium (Figure 3(D) and Figure 3(E)). Clade VI, with the maximum phylogenetic support $(\mathrm{BI}=1)$, was in turn divided into two sister 

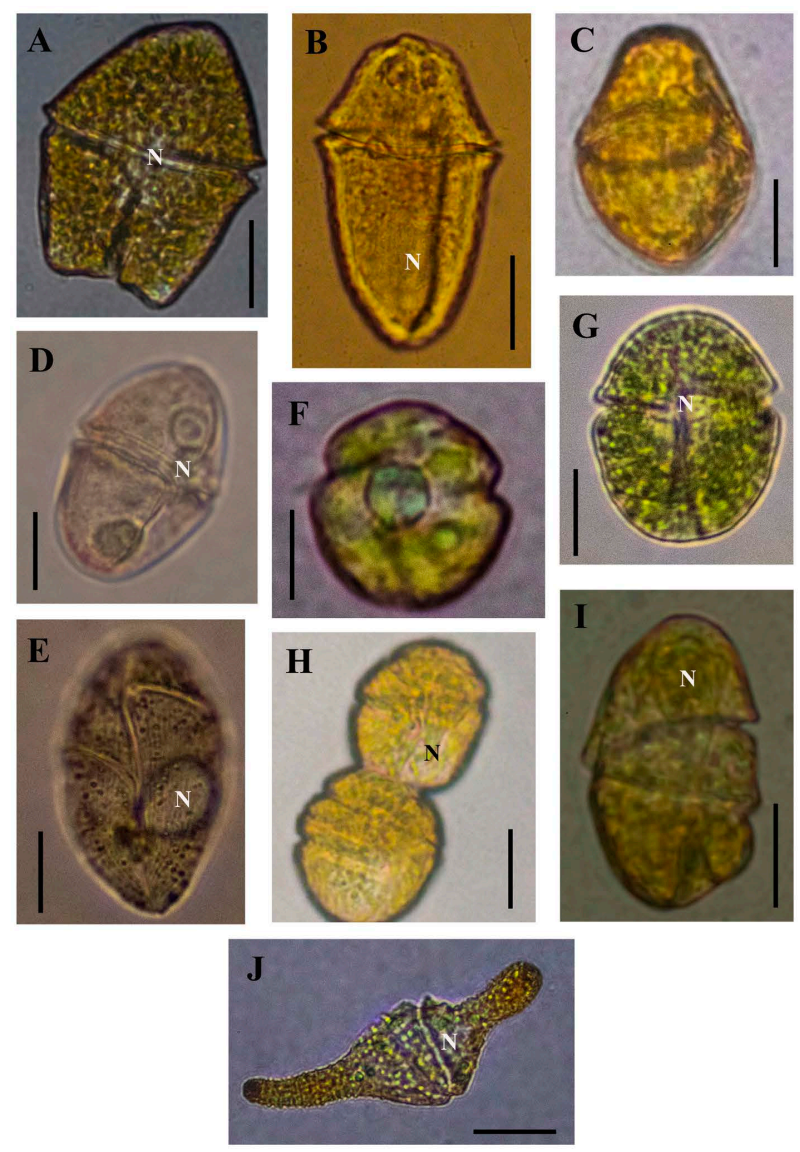

Figure 3. (A)-(J). A. Akashiwo sanguinea. (B). Balechina pachydermata. (C). Gymnodinium sp. 2 - sp. 3. (D). Gyrodinium heterostriatum. (E). Gyrodinium sp. 1. (F). Takayama tasmanica. (G). Lepidodinium viride. (H). Margalefidinium fulvescens. (I). Torquentidium flavescens. J. Pseliodinium fusus. The letter " $\mathrm{N}$ " indicates the position of the nucleus. Scale bar: (A), (C)-(J) $=20 \mu \mathrm{m}$; (B) $=30 \mu \mathrm{m}$.

subclades $(\mathrm{C}$ and $\mathrm{D})$. Subclade $\mathrm{C}$, with high phylogenetic support $(\mathrm{BI}=0.93)$, was made up of GenBank sequences of the genus Polykrikos. Subclade D, with low phylogenetic support $(\mathrm{BI}=0.56)$, was made up of the GenBank genera and generated in this study for the genus Lepidodinium (Figure $3(\mathrm{G})$ ), which in turn was resolved into a larger clade as a sister of Gymnodinium and Barrufeta, in turn, this clade formed a larger group with GenBank sequences generated in this study for the paraphyletic genus Gymnodinium (Figure 3(C)). Clade VII, with high phylogenetic support $(\mathrm{BI}=0.93)$, was made up of sequences generated in this study in an uncertain position.

Interspecific distances values with $18 \mathrm{~s}$ small subunit (SSU) ranged between a minimum of 3.2\% for Akashiwo sanguine - Takayama acrotrocha and a maximum of $>100 \%$ for Margalefidinium fulvescens - Gymnodinium impudicum. For $28 \mathrm{~s}$ large subunit (LSU) values ranged between a minimum of $19 \%$ for $A$. sanguinea-Karlodinium armiger and a maximum of $>100 \%$ for M. polykrikoides-Polykrikos kofoidii. Interspecific distance values are not included due to the large amount of data obtained. 


\section{Discussion}

Although our main aim was the molecular assessment of the species athecate dinoflagellates present in Todos Santos Bay, it was not possible in all cases, since the resulting phylogeny did not confirm its phylogenetic position. But it did show an important taxonomic problem in the current classification of the group at all hierarchical levels, which is discussed below.

The genus Margalefidinium, traditionally classified within the Gymnodiniaceae [28], appears in our analysis in a basal position, without any relationship with the species of this family. The interspecific distance values with Margalefidinium polykrikoides and M. fulvescens were even greater than $100 \%$, suggesting a total structure that seems to correspond to a taxonomic position above the family level. However, although with our present morphological and molecular data it is not possible to establish its taxonomic position, we can confirm phylogenetically the presence of $M$. fulvescens in the Bay. On the other hand, the genus Akashiwo, included within the Gymnodiniaceae family, showed a close relationship with the monospecific genus Levanderina, currently in an uncertain position [29], but not with the species of its current family. Previously, [10] had already suggested that this genus should be reclassified within a new family; our results support that Akashiwo does not belong to the Gymnodiniaceae family, and its phylogenetic position suggests that, together with Levanderina, they could comprise a new family supported by genetic distance values between them. In Bahía Todos Santos, we found representatives for both genera, those sequences close to Levanderina showed an intraspecific divergence of 3.3\%, which suggests a second species not yet described for this genus; in the case of the close sequences with Akashiwo sanguinea, they showed a similarity of $100 \%$, which confirms their presence in the bay, but not their taxonomic position.

The Kareniaceae grouped four of our sequences within the genus Takayama, two of which showed $100 \%$ similarity with T. tasmanica and a third $100 \%$ similarity with $T$. acrotrocha, confirming its presence in the bay and a new record for the Mexican Pacific. A fourth sequence, which presented a $99.9 \%$ similarity with Takayama sp., reported by [9], suggests a new phylogenetic entity not yet described. However, this work does not provide morphological data to complement our current data to describe them as a new species. The Ceratoperidiniaceae family, grouped five of our sequences, two of which showed $100 \%$ similarity with Pseliodinium fusus and three $99.5 \%$ with Torquentidium flavescens without percentage of genetic divergence between them, which confirmed their presence in the Bay and a new record for the Mexican Pacific (Figure 3(I)). Likewise, the sequences of $T$. convolutum, $T$. pirum and $T$. cf. helix, formed a monophyletic clade, without divergence between them, which suggests a possible misidentification of these sequences as distinct species. On the other hand, one of our sequences showed a 99\% similarity with Balechina pachydermata, the only species known for the genus [30], the sequences analyzed for this species did not show genetic divergence between them. Although the presence of this species in the 
bay is confirmed, its taxonomic position remains uncertain, however, it is suggested that a new family must be described to position this group.

For the Gyrodiniaceae, Gyrodinium grouped two of our sequences with Gyr. heterostriatum, Gyr. helveticum and Gyr. rubrum, strongly supported. Although the similarity between Gyr. helveticum and our sequence referred to as Gyrodinium sp. 1 was $99.5 \%$, its phylogenetic position does not support that both are the same species, although the values of genetic distance between them could confirm it. However, a detailed study with more precise markers and with a higher interspecific resolution could confirm their taxonomic position, since the morphological data that have been observed now suggest that they are different species. Our second sequence showed a $99.8 \%$ similarity to Gyr. heterostriatum, recently described by [31], with which we confirm its presence in the bay and a new record for the Mexican Pacific (Figure 3(D)). The range of genetic distance between the Gyrodinium species varied with SSU in $6.6 \%-24 \%$ and with LSU in $8.6 \%-19.4 \%$, much higher than the values of interspecific distances observed in other genera of the group, which shows the need to reevaluate the status of these species within Gyrodinium, including our sequences, as a part of only one genus.

For the Gimnodiniaceae, two of our sequences were grouped, showing $100 \%$ identity with Gymnodinium catenatum and Lepidodinium viride, the latter also being a new record (Figure $3(\mathrm{G})$ ), respectively, confirming their presence in the bay. On the other hand, in our phylogeny Gymnodinium constitutes a paraphyletic group within the family, a clade is made up of $G$. aureolum, another $G$. catenatum and $G$. nolleri and a last clade $G$. dorsalicum and $G$. impudicum. In previously published phylogenies [11] [32] [33], paraphilesis is also shown within this genus, so we consider it necessary to carry out a taxonomic restructuring. The clade made up of Lepidodinium species, with maximum support, was well differentiated from Gymnodinium, although one of the $L$. viride sequences was in the same clade as $G$. impudicum, but with a genetic distance of $10.3 \%$, which can be attributed to a misidentification of this sequence. Three of our sequences, identified by their morphological characteristics as species of the genus Gymnodinium, were grouped in a basal position without any relationship with others. The first sequence labeled Gymnodinium sp. 1, had a $90 \%$ similarity with Gertia stigmatica (a species not considered for this study) from GenBank, however, the sequences labeled Gymnodinium sp. 2 and sp. 3 presented the same morphotype and they had a $94 \%$ similarity with Karlodinium gentienii, but without any relationship with the species of the Kareniaceae family; they also presented a genetic divergence between $8.6 \%$ - 19.4\% with respect to Karlodinium. These results suggest that the three sequences correspond to a new family, a new genus, and new species, which must be described by detailed morphology.

Regarding the detection of FANS-forming species, it is important to have a precise characterization of the flora for Bahía Todos Santos, as an important site for aquaculture, since $\mathrm{HABs}$ are a worldwide problem that they mainly affect coastal areas, generating great effects in the economic (tourism, aquaculture, commercial and sport fishing) and health (public health) sectors, as well as wild- 
life. In toxic marine phytoplankton, dinoflagellates are the most important group in number and diversity, according to [34] and [35], 104 species of toxic dinoflagellates are listed, where 23 species correspond to athecate dinoflagellates, 19 for the order Gymnodiniales and four for the order Amphidiniales, of the total of athecates dinoflagellates, only 11 generate HABs. In this study we detected three harmful species (Akashiwo sanguinea, Levanderina fissa and Margalefidinium fulvescens), one toxic (Gymnodinium catenatum) and two potentially bloom-forming species (Lepidodinium viride and Takayama tasmanica), for the rest of the species their effect is unknown. In Mexico, there have been several epizootics related to the flowering of $A$. sanguinea, the last reported event was in 2007, where this species possibly caused anoxic conditions (abundance of $4.6 \times$ $10^{3}$ cells/l), which caused the massive death of benthic species in the North of Baja California Sur [36] [37] [38]. Levanderina fissa has been recorded in high abundances (from 163 to $265 \times 10^{3}$ cells/l) in Bahía de la Paz, Mexico, although the blooms of this species were harmless for the area [39]. M. fulvescens has been reported in lagoons and bays in the southern Gulf of California [40], being present in abundances of 600 to 45,800 cells/l, in La Paz Bay, Mexico [41], without causing any damage. Gymnodinium catenatum has recurrently formed FAN (since its description in 1943 to date) in different regions of the Mexican Pacific, presenting high densities $\left(1 \times 10^{6}\right.$ cells/l) in the northern part of the Gulf of California and little abundant records in the Mexican Tropical Pacific. This species produces paralyzing toxins, which is why it has caused poisoning in humans and wildlife [42] [43] [44]. The potentially bloom-forming species, Takayama tasmanica and Lepidodinium viride, have not been reported as toxic or harmful. $T$. tasmanica has been reported in Bahía de la Paz, with low abundance (400 - 600 cells/l) [45], in [46] point out that the species has occurred in great abundance along the East Coast and Gulf of the United States, without generating any repercussions. $L$. viride represents the first record for the Mexican Pacific, so there is no information on blooms of this species, however, [9] have reported this species as harmful, since it has been related to fish deaths on the shores of the Mediterranean Sea, due to oxygen depletion.

Finally, our analyses reveal the need to carry out an in-depth evaluation of the phylogenetic relationships within the athecate dinoflagellates at all hierarchical levels. Even though molecular tools are used in different parts of the world, as a complement in the diversity analysis in this group, now there is still not a deep interpretation of the phylogeny, being the preponderant criterion morphology over molecular evidence in the taxonomic decision making, generated an inconsistency in the integration of morphological and molecular results with the consequent instability in the current classification system.

\section{Acknowledgements}

We thank the Mexican Navy, Marine Secretariat (SEMAR), and Capitan C. Cap. Frag SMAM Nidia Teresa Angulo Larios and crew. We also thank Gabriel López Castillo, Judith León López, and Ludwinka Méndez González for their assistance 
with water sample collection and the crew of Universidad Autónoma de Baja California that carried out sampling campaigns in Bahía Todos Santos. This study was supported by the National Science and Technology Council [CONACyT; grant number CB2016283790].

\section{Conflicts of Interest}

The authors declare no conflicts of interest regarding the publication of this paper.

\section{References}

[1] Fensome, R.A., Taylor, F.J.R., Norris, G., Sarjeant, W.A.S., Wharton, D.I. and Williams, G.L. (1993) A Classification of Fossil and Living. Micropaleontology. Special Publication No. 7, Sheridan Press, Hanover.

[2] Licea, S., Moreno, J.L., Santoyo, H. and Figueroa, G. (1995) Dinoflagelados del Golfo de California. UABCS, SEP-FOMES y PROMARCO, México.

[3] Taylor, F.J.R., Hoppenrath, M. and Saldarriaga, J.F. (2008) Dinoflagellate Diversity and Distribution. Biodiversity and Conservation, 17, 407-418.

https://doi.org/10.1007/s10531-007-9258-3

[4] Gómez, F. (2005) A List of Free-Living Dinoflagellate Species in the World's Oceans. Acta Botanica Croatica, 64, 129-212.

[5] Guiry, M.D. and Guiry, G.M. (2021) AlgaeBase. World-Wide Electronic Publication, National University of Ireland, Galway. http://www.algaebase.org/

[6] Lindemann, E. (1928) Abteilung Peridineae (Dinoflagellatae). In: Engler, A. and Prantl, K., Eds., Die natürlichen Pflanzenfamilien nebst ihren Gattungen und wichtgeren Arten inbesodere den Nutzpflanzen unter Mirwirkung zahlreichter hervorrangender Fachgelehrten begründet vom, Verlag von Wilhelm Engleman, Leipzig, 3-104.

[7] Gómez, F., Moreira, D. and López-García, P. (2011) Avances en el estudio de los dinoflagelados (Dinophyceae) con la filogenia molecular. Hidrobiológica, 21, 343-364.

[8] Gómez, F., Moreira, D. and Lopez-Garcia, P. (2010) Molecular Phylogeny of Noctilucoid dinoflagellates (Noctilucales, Dinophyceae). Protist, 161, 466-478.

https://doi.org/10.1016/j.protis.2009.12.005

[9] Reñe, A., Camp, J. and Garcés, E. (2015) Diversity and Phylogeny of Gymnodiniales (Dinophycea) from the NW Mediterranean Sea Revealed by a Morphologycal and Molecular Approach. Protist, 166, 234-263. https://doi.org/10.1016/j.protis.2015.03.001

[10] Gómez, F. (2012) A Checklist and Classification of Living Dinoflagellates (Dinoflagellate, Alveolata). CICIMAR Oceánidades, 27, 65-140.

https://doi.org/10.37543/oceanides.v27i1.111

[11] Daugbjerg, N., Hansen, G., Larsen, J. and Moestrup, Ø. (2000) Phylogeny of Some of the Major Genera of Dinoflagellates Based on Ultrastructure and Partial LSU rDNA Sequence Data, Including the Erection of Three New Genera of Unarmoured Dinoflagellates. Phycologia, 39, 302-317. https://doi.org/10.2216/i0031-8884-39-4-302.1

[12] Hu, Z., Deng, Y., Li, Y. and Tang, Y.Z. (2018) The Morphological and Phylogenetic Characterization for the Dinoflagellate Margalefidinium fulvescens (=Cochlodinium fulvescens) Isolated from the Jiaozhou Bay, China. Acta Oceanologica Sinica 37, 11-17. 
https://doi.org/10.1007/s13131-018-1295-0

[13] Hyeon, H.S., Zhun, L. and Kazumi, M. (2020) Reclassification of Gyrodinium flavescens Kofoid \& Swezy as Torquentidium flavescens comb.nov. (Ceratoperidiniaceae, Dinophyceae), Based on Morphology and Phylogeny. Phycologia, 5, 133-139. https://doi.org/10.1080/00318884.2019.1709396

[14] Takahashi, K., Benico, G., Mun-Lum, W. and Iwataki, M. (2019) Gertia stigmatica gen. et sp. nov. (Kareniaceae, Dinophyceae), a New Marine Unarmored Dinoflagellate Possessing the Peridinin-Type Chloroplast with an Eyespot. Protist, 170, Article ID: 125680. https://doi.org/10.1016/j.protis.2019.125680

[15] Ok, J.H., Jeong, H.J., Lee, S.Y., Park, S.A. and Noh, J.H. (2021) Shimiella gen. nov. and Shimiella gracilenta sp. nov. (Dinophyceae, Kareniaceae), a Kleptoplastidic Dinoflagellate from Korean Waters and Its Survival under Starvation. Journal of Phycology, 50, 70-91. https://doi.org/10.1111/jpy.13067

[16] Esqueda-Lara, K. and Hernandez-Becerril, D.U. (2010) Dinoflagelados microplanctonicos marinos del Pacifico central de México) Isla Isabel, Nayarit y costas de Jalisco y Colima. Instituto de Ciencias del Mar y Limnología. Universidad Nacional Autónoma de México, México.

[17] Meave-del Castillo, M.E., Zamudio-Reséndiz, M.E. and Castillo-Rivera, M. (2012) Riqueza fitoplanctónica de la Bahía de Acapulco y zona costera Aledaña, Guerrero, México. Acta Botánica Mexicana, No. 100, 405-487. https://doi.org/10.21829/abm100.2012.41

[18] Almazán-Becerril, A., Aké-Castillo, J.A., García-Mendoza, E., Sánchez-Bravo, Y.A., Escobar-Morales, S. and Valadez Cruz, F. (2016) Catálogo de microalgas de Bahía de Todos Santos, Baja California. CICESE, México.

[19] García-Mendoza, E., Cáceres-Martínez, J., Rivas, D., Fimbres-Martinez, M., Sánchez-Bravo, Y., Vásquez-Yeomans, R. and Medina-Elizalde, J. (2018) Mass Mortality of Cultivated Northern Bluefin Tuna Thunnus thynnus orientalis Associated with Chattonella Species in Baja California, Mexico. Frontiers in Marine Science, 5, Article No. 454. https://doi.org/10.3389/fmars.2018.00454

[20] Matsuoka, K., Kawami, H., Fuji, R. and Iwataki, M. (2006) Further Examination of the Cyst-Theca Relationship of Protoperidinium thulense (Peridiniales, Dinophyceae) and the Phylogenetic Significance of Round Brows Cysts. Phycologia, 45, 632-641. https://doi.org/10.2216/05-42.1

[21] Hernández-Rosas, A., Meave-del Castillo, M.E., Díaz-Larrea, J. and Rodríguez, F. (2018) Single-Cell PCR Amplification of Thecate Dinoflagellates: A Case Study of Tripos (Dinophyceae). Journal of Applied Phycology, 30, 1117-1124.

https://doi.org/10.1007/s10811-017-1269-1

https://link.springer.com/article/10.1007/s10811-017-1269-1

[22] Scholin, C.A., Herzog, M., Sogin, M. and Anderson, D.M. (1994) Identification of Group and Strain-Specific Genetic Markers for Globally Distributed Alexandrium (Dinophyceae) II. Sequence análisis of a Fragmento the Large Subunit Ribosomal RNA Gene. Journal of Phycology, 30, 999-1011. https://doi.org/10.1111/j.0022-3646.1994.00999.x

[23] Hansen, G., Daugbjerg, N. and Henriksen, P. (2000) Comparative Study of Gymnodinium mikimotoi and Gymnodinium aureolum, comb. Nov. (=Gymnodinium aureolum) based on morphology, Pigment and Composition and Molecular Data. Journal of Phycology, 36, 394-410. https://doi.org/10.1046/j.1529-8817.2000.99172.x

[24] Hall, T.A. (1999) BioEdit a User-Friendly Biological Sequence Alignment Editor and Analysis Program for Windows 95/98/NT. Nucleic Acids Symposium Series, 
41, 95-98.

[25] Ronquist, F., Teslenko, M., Van Der Mark P., Ayres, D.L., Darling, A., Hohna, S., Larget, B., Liu, L., Suchard, M.A. and Huelsenbeck, J.P. (2012) MrBayes 3.2: Efficient Bayesian Phylogenetic Inference and Model Choice across a Large Model Space. Systematic Biology, 61, 539-542. https://doi.org/10.1093/sysbio/sys029

[26] Milne, I., Lindner, D., Bayer, M., Husmeier, D., McGuire, G., Marshall, D.F. and Wright, F. (2009) TOPALi v2: A Rich Graphical Interface for Evolutionary Analyses of Multiple Alignments on HPC Clusters and Multi-Core Desktops. Bioinformatics, 25, 126-127. https://doi.org/10.1093/bioinformatics/btn575

[27] Tamura, K., Peterson, D., Peterson, N., Stecher, G., Nei, M. and Kumar, S. (2011) MEGA5: Molecular Evolutionary Genetics Analysis Using Maximum Likelihood, Evolutionary Distance, and Maximum Parsimony Methods. Molecular Biology and Evolution, 28, 2731-2739. https://doi.org/10.1093/molbev/msr121

[28] Gómez, F., Richlen, M.L. and Anderson, D.M. (2017) Molecular Characterization and Morphology of Cochlodinium strangulatum, the Type Species of Cochlodinium, and Margalefidinium gen.nov. for $C$. polykrikoides and Allied Species (Gymnodiniales, Dinophyceae). Harmful Algae, 63, 32-44.

https://doi.org/10.1016/j.hal.2017.01.008

[29] Moestrup, Ø., Hakanen, P., Hansen, G., Daugbjerg, N. and Ellegaard, M. (2014) On Levanderina fissa Gen. \& Comb. nov. (Dinophyceae) (syn. Gymnodinium fissum, Gyrodinium instriatum, Gyr. uncatenatum), a Dinoflagellate with a Very Unusual sulcus. Phycologia, 53, 256-292. https://doi.org/10.2216/13-254.1

[30] Gómez, F., López-García, P., Takayama, H. and Moreira, D. (2015) Balechina and the New Genus Cucumeridinium gen. nov. (Dinophyceae), Unarmored Dinoflagellate with Thick Cell Coverings. Journal of Phycology, 51, 1088-1105. https://doi.org/10.1111/jpy.12346

[31] Gómez, F., Artigas, L.F. and Gast, R.J. (2020) Phylogeny and Synonymy of Gyrodinium heterostriatum Comb. nov. (Dinophyceae), a Common Unarmored Dinoflagellate in the World Oceans. Acta Protozoologica, 59, 77-98. https://doi.org/10.4467/16890027AP.20.007.12675

[32] De Salas, M.F., Bolch, C.J.S., Botes, L., Nash, G., Wright, S.W. and Hallegraeff, G.M. (2003) Takayama gen. nov. (Gymnodiniales, Dinophyceae), a New Genus of Unarmoured Dinoflagellates with Sigmoid Apical Grooves, Including the Description of Two New Species. Journal of Phycology, 39, 1233-1246. https://doi.org/10.1111/j.0022-3646.2003.03-019.x

[33] De Salas, M.F., Bolch, C.J. S. and Hallegraeff, G.M. (2004) Karenia asterichroma sp. nov. (Gymnodiniales, Dinophyceae), a New Dinoflagellate Species Associated with Finfish Aquaculture Mortalities in Tasmania, Australia. Phycologia, 43, 624-631. https://doi.org/10.2216/i0031-8884-43-5-624.1

[34] Moestrup, Ø., Akselmann-Cardella, R., Churro, C., Fraga, S., Hoppenrath, M., Iwataki, M., Larsen, J., Lundholm, N. and Zingone, A. (2009) IOC-UNESCO Taxonomic Reference List of Harmful Micro Algae. http://www.marinespecies.org/hab

[35] Hansen, G. (2021) Gymnodiniales. In: Lundholm, N., Churro, C., Fraga, S., Iwataki, M., Larsen, J., Mertens, K., et al., Eds., IOC-UNESCO Taxonomic Reference List of Harmful Micro Algae. http://www.marinespecies.org/hab

[36] Ochoa, J.L., Sanchez-Paz, A., Cruz-Villacorta, A., Núñez-Vázquez, E.J. and Sierra-Beltran, A.P. (1997) Toxic Events in the North Pacific Coastline in Mexico during 1992-1995: Origin and Impact. Hydrobiologia, 352, 195-200.

https://doi.org/10.1023/A:1003015103760 
[37] Sierra-Beltrán, A.P., Cruz, A., Núñez-Vázquez, E.J., Del Villar, L.M., Cerecero, J. and Ochoa, J.L. (1998) An Overview of the Marine Food Poisoning in Mexico. Toxicon, 36, 1493-1502. https://doi.org/10.1016/S0041-0101(98)00139-1

[38] Gárate-Lizárraga, I., Pérez-Cruz, B., Díaz-Ortiz, J. and Band-Schmidt, C.J. (2008) Microalgas y biotoxinas marinas en las costas mexicanas. Conversus, 9, 22-26.

[39] Gárate-Lizárraga, I. (2014) Proliferation of Levanderina fissa and Polykrikos hartmannii (Dinophyceae: Gymnodiniales) in Bahía De La Paz, Gulf of California, México. CICIMAR Oceánides, 29, 25-35. https://doi.org/10.37543/oceanides.v29i2.137

[40] Morquecho-Escamilla, M.L. and Alonso-Rodríguez, R. (2008) First Record of Cochlodinium fulvescens in Mexican Pacific. Harmful Algae News, 37, 5-6.

[41] Gárate-Lizárraga, I. (2014) Ocurrence of Cochlodinium fulvescens (Gymnodiniales: Dinophyceae) in the Southwestern Gulf of California. Revista de Biología Marina $y$ Oceanografía, 49, 123-127. https://doi.org/10.4067/S0718-19572014000100013

[42] Mee, L.D., Espinosa, M. and Díaz, G. (1986) Paralytic Shellfish Poisoning with a Gymnodinium catenatum Red Tide on the Pacific Coast of Mexico. Marine Environmental Research, 19, 77-92. https://doi.org/10.1016/0141-1136(86)90040-1

[43] Cortés-Altamirano, R. and Sierra-Beltrán A.P. (2008) Biotoxins from Freshwater and Marine Harmful Algal Blooms Occurring in Mexico. Toxin Reviews, 27, 27-77. https://doi.org/10.1080/15569540701883437

[44] Band-Schmidt, C.J., Bustillos-Guzmán, J.J., López-Cortes, D.J., Gárate-Lizárraga, I., Núñez-Vázquez, E.J. and Hernández-Sandoval, F.E. (2010) Ecological and Physiological Studies of Gymnodinium catenatum in the Mexican Pacific. Marine Drugs, 8, 1935-1961. https://doi.org/10.3390/md8061935

[45] Garate-Lizarraga, I. (2014) Unarmored Dinoflagellates Present during a Bloom of Cetatoperidinium falcatum in Bahia de la Paz, Gulf of California. Revista de Biología Marina y Oceanografía, 49, 577-587. https://doi.org/10.4067/S0718-19572014000300014

[46] Anderson, D.M., Fensin, E., Glober, C.J., Hoeglund, A.E., Hubbard, K.A., Kulis, D.M., Landsberg, J.H., Lefebvre, K.A., Provoost, P., Richlen, M.L., Smith, J.L., Solow, A.R. and Trainer, V.L. (2021) Marine Harmful Algal Blooms (HAB,s) in the United States: History, Current Status and Futures Trends. Harmful Algae, 102, Article ID: 101975. https://doi.org/10.1016/j.hal.2021.101975 


\section{Supplement}

Table S1. GenBank $18 \mathrm{~s}$ small subunit (SSU) and $28 \mathrm{~s}$ large subunit (LSU) sequence data used for phylogenetic analysis. The dash (-) indicates that there is no collection record.

\begin{tabular}{|c|c|c|}
\hline Taxa & Distribution data & $\begin{array}{c}\text { GenBank } \\
\text { accession } \\
\text { number }\end{array}$ \\
\hline $\begin{array}{c}\text { Akashiwo sanguine } \\
\text { (Hirasaka) Hansen \& Moestrup }\end{array}$ & Tolo Harbor (Hong Kong) & MG890411 \\
\hline A. sanguinea & Soko Islands (Hong Kong) & MG890410 \\
\hline A. sanguinea & Gruissan, Ayrolle Lagoon (France) & MT373696 \\
\hline A. sanguinea & Soko Islands (Hong Kong) & MG914054 \\
\hline A. sanguinea & Jangmok Bay (Korea) & MK571208 \\
\hline A. sanguinea & Jangmok Bay (Korea) & MK571209 \\
\hline $\begin{array}{c}\text { Balechina pachydermata } \\
\text { (Kofoid \& Swezy) Loeblich Jr., } \\
\text { Loeblich III }\end{array}$ & Port of Valencia (Spain) & KR139789 \\
\hline B. pachydermata & Sao Sebastiao Channel (Brazil) & KR139790 \\
\hline B. pachydermata & Sao Sebastiao Channel (Brazil) & KR139792 \\
\hline $\begin{array}{l}\text { Barrufeta resplendens } \\
\text { Sampedro \& Fraga }\end{array}$ & Gulf of Mexico & KT203382 \\
\hline $\begin{array}{l}\text { Bar. bravensis (Hulburt) } \\
\quad \text { Gu, Lu \& Mertens }\end{array}$ & $\begin{array}{c}\text { Northwest Mediterranean Sea } \\
\text { (Spain) }\end{array}$ & FN647673 \\
\hline $\begin{array}{c}\text { Ceratoperidinium } \\
\text { margalefii Loeblich III }\end{array}$ & $\begin{array}{c}\text { Catalonia, La Muga river mouth } \\
\text { (Spain) }\end{array}$ & KF245456 \\
\hline $\begin{array}{l}\text { Gymnodinium aureolum } \\
\text { (Hulburt) Hansen }\end{array}$ & Benguela Current (Namibia) & AY999082 \\
\hline G. catenatum Graham & Manila Bay (Philippines) & AB265962 \\
\hline G. catenatum & Southern Coast (Korea) & MK215823 \\
\hline $\begin{array}{c}\text { G. dorsalisulcum } \\
\text { (Hulbert, McLaughlin \& Zahl) } \\
\text { Shauna, Salas \& Hallegraeff }\end{array}$ & Perhentian Island (Malaysia) & MH732684 \\
\hline $\begin{array}{c}\text { G. impudicum (Fraga \& Bravo) } \\
\text { Hansen \& Moestrup }\end{array}$ & Hase (South Korea) & DQ779993 \\
\hline G. impudicum & $\begin{array}{c}\text { Corsica, } \\
\text { Mediterranean Sea (France) }\end{array}$ & MH732686 \\
\hline G. nolleri Ellegaard \& Moestrup & - & AF200673 \\
\hline $\begin{array}{c}\text { Gyrodinium cf. } \\
\text { britannicum Kofoid \& Swezy }\end{array}$ & Catalan Coast & KP790191 \\
\hline Gyr. corallinum Kofoid \& Swezy & Catalan Coast & KP790192 \\
\hline Gyr. dominans Hulbert & Masan (South Korea) & FN669510 \\
\hline
\end{tabular}




\section{Continued}

Gyr. fusiforme Kofoid \& Swezy Gyr. helveticum (Penard)

Takano \& Horiguichi

Gyr. helveticum

Gyr. helveticum

Gyr. heterogrammun Larsen

Gyr. heterogrammun

Gyr. heterostriatum (Kofoid \& Swezy) Gómez, Artigas \& Gast

Gyr. moestrupii Yoon, Kang \& Jeong

Gyr. rubrum (Kofoid \& Swezy) Takano \& Horiguichi

Gyr. rubrum

Gyr. spirale (Bergh)

Kofoid \& Swezy

Gyr. spirale

Gyr. viridescens Kofoid \& Swezy

Hematodinium perezi

Chatton \& Poisson

Karenia brevis (Davis)

Hansen \& Moestrup

$$
\text { K. brevis }
$$

K. brevisulcata (Chang)

Hansen \& Moestrup

K. cristata Botes, Sym \& Pitcher

$$
\text { K. mikimotoi }
$$

(Miyake \& Kominami ex Oda)

Hansen \& Moestrup

$$
\text { K. mikimotoi }
$$

K. selliformis Haywood \& Steidinger \& MacKenzie

Karlodinium armiger Bergholtz,

Daugbjerg \& Moestrup

Kar. ballantinum Salas

Kar. gentienii Nézan,

Chomérat \& Siano

Kar. jujuense Li \& Shin

Kar. zhouanum Luo \& Gu

$$
\text { Otaru Bay (Japan) }
$$

AB120002

$$
\text { Lake Shikotsu (Japan) }
$$$$
\text { Lake Baikal (Russia) }
$$$$
\text { Lake Baikal (Russia) }
$$

Catalan Coast

Catalan Coast

AB120004

FJ024299

MG493227

KP790158

KP790196

North Sea (Netherlands)

MT677911

Western Korea

HE611580

Otaru Bay (Japan)

AB120003

AY571369

Otaru Bay (Japan)

AB120001

Otaru Bay (Japan)

AY571371

Catalan Coast

KP790208

EF0655717

Gulf of Mexico

AF352818

Corpus Christi, Texas (USA)

AY355455

Concarneau Bay (France)

KJ508359

South African Coast

AY243963

EF492505

New Caledonia

KJ508365

New Zealand

HM067007

Catalan Coast

KP790218

Manila Bay (Philippines)

LC521284

Brest Bay (France)

KJ508378

Northern East China Sea

KX519410 


\section{Continued}
Kirithra asteri Boutrup, Tillmann, Daugbjerg \& Moestrup
Kir. sigma $\mathrm{Hu}$, Zhun,Shin \& Tang
Levanderina fissa (Levander) Moestrup, Hakanen, Hansen,
Daugbjerg \& Ellegaard

$$
\begin{aligned}
& \text { L.fissa } \\
& \text { L.fissa }
\end{aligned}
$$$$
\text { L.fissa }
$$

Lepidodinium chlorophorum

(Elbrächter \& Schnepf)

Hansen, Botes \& Salas

Lep. chlorophorum

Lep. chlorophorum

Lep. chlorophorum

Lep. viride Watanabe, Suda, Inouye, Sawaguchi \& Chihara

$$
\begin{aligned}
& \text { Lep. viride } \\
& \text { Lep. viride }
\end{aligned}
$$

Margalefidinium polykrikoides (Margalef) Gómez, Richlen, Anderson

M. polykrikoides

M. fulvescens

(Iwataki, Kawami \& Matsuoka)

Gómez, Richlen \& Anderson

$$
\begin{aligned}
& \text { M. fulvescens } \\
& \text { M. fulvescens } \\
& \text { M. fulvescens }
\end{aligned}
$$

Pseliodinium fusus

(Schütt) Gómez

$$
P \text {. fusus }
$$

Polykrikos cf. schwartzii Bütschli

Pol. Herdmaniae

Hoppenrath \& Leander

Pol. herdmaniae

Pol. kofoidii Chatton

Pol. kofoidii

Pol. lebouriae Herdman
Argentina

China

New River estuary (USA)

Korean coasts

Long Island Sound

Catalan Coast

Brest Bay (France)

KJ508396

AM184122

AB367942

South Africa

Catalan Coast

Gulf of Naples (Italy)

Korean coasts

Lampung Bay (Indonesia)

Hurum Bay (Indonesia)

Santa Monica Bay (USA)

Jiaozhou Bay (China)

California (USA)

Catalan Coast

Douarnenez Bay (France)

KJ508394

AY526522

DQ822481

Catalan Coast

KP790225

DQ371291

EF613367

DQ975472 


\section{Continued}

\begin{tabular}{|c|c|c|}
\hline Pol. lebourae & - & FJ947044 \\
\hline Pol. tanit Reñé & Arenys Harbour, Catalonia (Spain) & KF806598 \\
\hline Syndinium turbo Chatton & - & DQ146404 \\
\hline $\begin{array}{l}\text { Takayama cf. pulchellum (Larsen) } \\
\text { Salas, Bolch \& Hallegraeff }\end{array}$ & Xiamen Harbor (China) & AY800130 \\
\hline $\begin{array}{l}\text { T. acrotrocha (Larsen) Salas, } \\
\text { Bolch \& Hallegraeff }\end{array}$ & Italy & HM067010 \\
\hline T. acrotrocha & Singapore & DQ656117 \\
\hline $\begin{array}{l}\text { T. helix Salas, Bolch, } \\
\text { Botes \& Hallegraeff }\end{array}$ & North West Bay (Autralia) & AY284950 \\
\hline$T$ sp. & Quiberon Bay (France) & KJ508388 \\
\hline $\begin{array}{l}\text { T. tasmanica Salas, } \\
\text { Bolch \& Hallegraeff }\end{array}$ & Tuggerah Lakes (Australia) & AY284949 \\
\hline T. tasmanica & East China Sea & KC485077 \\
\hline T. tasmanica & Catalan Coast & KP790230 \\
\hline T. tuberculata Salas & Southern Ocean (Australian) & EF469230 \\
\hline $\begin{array}{l}\text { Torquentidium cf. helix (Pouchet) } \\
\text { Shin, Li, Lee \& Matsu }\end{array}$ & Tasmania, Nubeena (Australia) & KF245459 \\
\hline $\begin{array}{l}\text { Tor. convolutum (Kofoid \& Swezy) } \\
\text { Shin, Li, Lee \& Matsu }\end{array}$ & - & MF948385 \\
\hline Tor. convolutum & East China Sea & MF948386 \\
\hline $\begin{array}{l}\text { Tor. flavescens (Kofoid \& Swezy) } \\
\quad \text { Shin, Li, Lee \& Matsuoka }\end{array}$ & - & MK733283 \\
\hline Tor. flavescens & - & MK733280 \\
\hline $\begin{array}{l}\text { Tor. pirum (Schütt) Shin, } \\
\text { Li, Lee \& Matsuoka }\end{array}$ & Jiaozhou Bay (China) & MH469535 \\
\hline
\end{tabular}

